\title{
Role of nasal douching in chronic allergic rhinitis
}

\author{
Saxena R.K. ${ }^{1}$, Bamaniya H. ${ }^{2}$, Bhuie H.S. ${ }^{3}$ \\ ${ }^{1}$ Dr. Rajiv Kumar Saxena, Associate Professor, ${ }^{2}$ Dr. Hemendra Bamaniya, Associate Professor, ${ }^{3}$ Dr. H.S. Bhuie, \\ Professor, all authors are affiliated with Department of ENT, Ananta Institute of Medical Sciences, Rajsamand, \\ Rajasthan, India.
}

Corresponding Author: Dr. Hemendra Bamaniya, Associate Professor, Department of ENT, Ananta Institute of Medical Sciences, Rajsamand, 25+26-C, Rama Vihar, Meera Nagar, Behind Banera Castle Garden, Shobhagpura 100 Feet Road, Bhuwana, Udaipur (Rajasthan). E-mail: dr_hemendra83@yahoo.com

\begin{abstract}
Objective: The present study was carried out to evaluate the role of nasal douching in the treatment of allergic rhinitis using daily allergic rhinitis symptom score. Material \& Methods: 120 patients of chronic allergic rhinitis who attended otorhinolaryngology outdoor of Ananta Institute of Medical Sciences, Rajsamand, Rajasthan were included in the study. patients were divided into two equal groups viz. group $\mathbf{A}(\mathrm{n}=60)$ in which patients were treated with antihistamincs, leukotriene receptor antagonists and intranasal steroid sprays and group $\mathbf{B}(\mathrm{n}=60)$ in which isotonic saline nasal douching was advised to the patients three times a day as an adjunctive to the medical treatment. Patients were followed up after 2 week and 4 weeks. Mean daily allergic rhinitis symptom score were calculated at each follow up and compared between the two groups. Results: out of 120 patients, 63 were male and 57 were female. Age of the patients ranges from 20 to 60 years with the mean age of 36.5 years. Mean daily rhinitis scores of group A and group B were $14.6 \pm 1.6$ and $14.3 \pm 2.0$ respectively ( $\mathrm{p}$ value- 3.661 ) which was reduced to $8.9 \pm 2.1$ and $7.1 \pm 1.8$ respectively and the difference was found to be statistically significant ( $\mathrm{p}$ value $<0.0001$ ). At 4 th week follow up, the scores of were further reduced to $3.8 \pm 1.7$ and $2.2 \pm 0.9$ respectively and the difference was found to be statistically significant ( $\mathrm{p}$ value $<0.0001$ ). Conclusion: Nasal douching is an effective method to manage symptoms of allergic rhinitis when used along with other medical treatment including intranasal steroids, antihistaminics and leukotriene receptor antagonists.
\end{abstract}

Keywords: Allergic Rhinitis, Nasal irrigation, Rhinorrhoea, Intranasal steroids, Allergen.

\section{Introduction}

Rhinitis is defined as an inflammation of nasal mucosa and is characterized by symptoms like nasal itching, clear rhinorrhoea, nasal obstruction and sneezing. When symptoms of rhinitis are triggered by an allergen, the resulting condition is referred to as allergic rhinitis. Allergic rhinitis may be seasonal, perennial, or may occur sporadically after specific exposures. Allergic rhinitis can be intermittent ( $<$ four days/week or four weeks/year) or persistent (>four days/week, or four weeks /year).

Allergic rhinitis leads to a significant impairment in the quality of life of the patients when measured by various quality of life instruments [1,2]. It can also lead to fatigue and daytime sleepiness, reduced work productivity, impaired cognitive functioning, reduced learning abilities, and impaired sleep [1,3-10].

Manuscript received: $4^{\text {th }}$ May 2019

Reviewed: $10^{\text {th }}$ May 2019

Author Corrected: $14^{\text {th }}$ May 2019

Accepted for Publication: $18^{\text {th }}$ May 2019
Nasal douching (also known as nasal irrigation, nasal lavage) is a procedure to rinse the nasal cavity with saline solution. It is an old practice for cleaning and care of upper respiratory tract that was originated in the Ayurvedic medical tradition [11]. Since then the procedure is accepted worldwide as an effective method to treat and prevent upper respiratory tract diseases [12-17].

Nasal saline irrigation is believed to work through making the mucus thinner, making it easy to remove and also by removing some of the allergens from the nasal cavity and by enhancing the mucociliay mechanism. Solution for nasal douching can be isotonic saline $(0.9 \% \mathrm{NaCl})$ and hypertonic saline $(1.5 \%$ to $3 \%$ $\mathrm{NaCl})$. Both are acidic solutions, with $\mathrm{pH}$ varying from 4.5 to 7 .

In present study, we used isotonic saline solution for douching purpose. 


\section{Original Research Article}

\section{Material \& Methods}

The present study is a prospective study carried out in Department of Otorhinolaryngology, Ananta Institute of Medical sciences, Rajsamand, Rajasthan during the period from February 2017 to February 2019.

\section{Setting: Tertiary care}

Type of study: Prospective, longitudinal study

Participants: 120 patients attended ENT OPD with the symptoms of allergic rhinitis (sneezing, rhinorrhoea, itching in nose) were included in the study. Complete ENT examination of the patients was carried out.

Types of participants: All the 120 patients included in the study were divided into following two groups:

Group A (n=60): patients were treated with antihistamincs, leukotriene receptor antagonists and intranasal steroid sprays.

Group B $(\mathrm{n}=60)$ : isotonic saline nasal douching was advised to the patients three times a day as an adjunctive to the treatment with antihistaminics, leukotriene receptor antagonists and intranasal steroids.

Type of intervention: Participants of group B were advised to perform nasal douching using isotonic nasal solution three times a day.

An easy home remedy was told to all the patients to prepare isotonic solution: $\operatorname{mix} 250 \mathrm{ml}$ of boiled and cooled water with $1 / 4$ teaspoonful common salt $(\mathrm{NaCl})$ and $1 / 4$ teaspoonful baking soda $(\mathrm{NaHCO} 3)$. Patients were advised to use the freshly prepared solution every time and were taught to perform nasal douching using 20cc syringe.

\section{Results}

A total of 120 patients were included in present study out of which 63 were male and 57 were female.Age of the patients ranges from 20 to 60 years with the mean age of 36.5 years. All the 120 patients included in the study were divided into following two groups:

Group A (n=60): patients were treated with antihistamincs, leukotriene receptor antagonists and intranasal steroid sprays.

Group B $(n=60)$ : isotonic saline nasal douching was advised to the patients three times a day as an adjunctive to the treatment with antihistaminics, leukotriene receptor antagonists and intranasal steroids

Both the groups were matched for age, gender and severity of symptoms.

Patients were followed up after 2 week and 4 week. Patients were told to calculate and record their daily allergic rhinitis symptom score on diary card given to them. Intensity of theses four symptoms were rated as per a 5 graded scale: 0 - no symptom, 1- slight, 2- mild, 3- moderate, 4- severe. Total score ranges from 0 to 16. Mean score of these daily data were calculated on each follow up. The results are depicted in table. 1 
Initially, Mean daily rhinitis scores of group A and group B were $14.6 \pm 1.6$ and $14.3 \pm 2.0$ respectively and the difference was not significant ( $\mathrm{p}$ value- 3.661 ).

At 2nd week follow up, mean daily rhinitis scores of group A and group B were reduced to $8.9 \pm 2.1$ and $7.1 \pm 1.8$ respectively. Similarly, at 4th week follow up, mean daily rhinitis scores of group A and group B were further reduced to $3.8 \pm 1.7$ and $2.2 \pm 0.9$ respectively. The difference was found to be statistically significant ( $p$ value $<0.0001$ ) during each follow up.

Table-1: Mean daily score of group A and group B at start of therapy and at each follow up.

\begin{tabular}{|c|c|c|c|c|}
\hline & & Group A & Group B & P-value \\
\hline Mean Daily & At start of therapy & $14.6 \pm 1.6$ & $14.3 \pm 2.0$ & 0.3661 \\
\cline { 2 - 5 } $\begin{array}{c}\text { Rhinitis Score } \\
\text { (Mean } \pm \text { SD) }\end{array}$ & At $2^{\text {nd }}$ week follow-up & $8.9 \pm 2.1$ & $7.1 \pm 1.8$ & $<0.0001$ \\
\cline { 2 - 5 } & At $4^{\text {th }}$ week follow-up & $3.8 \pm 1.7$ & $2.2 \pm 0.9$ & $<0.0001$ \\
\hline
\end{tabular}

Group A: patients were treated with antihistamincs, leukotriene receptor antagonists and intranasal steroid sprays. Group B: isotonic saline nasal douching was advised to the patients three times a day as an adjunctive to the treatment with antihistaminics, leukotriene receptor antagonists and intranasal steroids

\section{Discussion}

Allergic rhinitis leads to a significant impairment in the quality of life of the patients when measured by various quality of life instruments. Besides this, allergic rhinitis also increases the healthcare cost because the treatment requires multiple consultations and chronic medical therapy.

Nasal irrigation is a procedure to rinse the nasal cavity with saline solution. It is now accepted globally as an effective method to treat and prevent recurrent upper respiratory tract infection and allergies. Nasal irrigation works by many physiological effects including 1 . Cleaning the nasal cavity as saline thins and removes the mucus and crusts, 2. Removal and decrease production of various inflammatory mediators like histamine, prostaglandins, leukotriens etc. 3. Enhancing the mucociliary clearance mechanism [19-24].

In present study, we advised the patients of allergic rhinitis to perform isotonic saline nasal douching three times a day as an adjunctive to the medical treatment (group B) and the results were assessed in form of mean daily rhinitis score and compared with other group of patients who were treated with medical treatment only (group A). Patients were followed up after a period of 2 week and 4 week and the mean daily rhinitis score were calculated during each follow up.

Mean daily rhinitis scores of group A and group B were $14.6 \pm 1.6$ and $14.3 \pm 2.0$ respectively (p value- 3.661 ). At 2nd week follow up, mean daily rhinitis scores of group A and group B were reduced to $8.9 \pm 2.1$ and $7.1 \pm 1.8$ respectively and the difference was found to be statistically significant ( $\mathrm{p}$ value $<0.0001$ )
At 4th week follow up, mean daily rhinitis scores of group A and group B were further reduced to $3.8 \pm 1.7$ and $2.2 \pm 0.9$ respectively and the difference was found to be statistically significant ( $\mathrm{p}$ value $<0.0001$ ).

The results are suggestive that isotonic saline irrigation is very effective in treatment of allergic rhinitis when used as an adjunctive to the treatment with antihistaminics, leukotriene receptor antagonists and intranasal steroids.

Similar study done in the past on the woodworkers $(n=45)$, exposed to varying level of wood dust, were advised to perform isotonic saline nasal irrigation daily and demonstrated significant improvement in sinus symptoms, mucociliary clearance and expiratory nasal flow [25].

In present study, we used isotonic saline solution $(0.9 \%$ $\mathrm{NaCl})$ for nasal irrigation three times a day for 4 weeks. Previous studies have been done with hypertonic solution $(>0.9 \% \mathrm{NaCl})$.

Shose you et al found that hypertonic saline is effective in treatment of allergic rhinitis but its use can lead to inflamed nasal mucosa due to local irritation [26]. Similar study done by Baraniuk et al suggested that hypertonic saline irrigation leads to release of substance $\mathrm{P}$ and glandular secretion due to stimulation of nociceptive nerves, which causes pain to the patient [27].

Such types of side effects are not seen with isotonic saline solution. 
Other studies done in the past also reported the reduction in nasal symptoms after long term use of nasal irrigation $[28,29]$ except one study done by Nsouli et al, who hypothesized that daily nasal irrigation in healthy adults, could lead to an increase in the number of upper respiratory tract infections [30].

\section{Conclusion}

Nasal irrigation with isotonic saline solution is a safe, inexpensive and effective method to manage symptoms of allergic rhinitis when used along with other medical treatment including intranasal steroids, antihistaminics and leukotriene receptor antagonists. Isotonic solution has no side effects and it helps in decreasing the healthcare cost by reducing the need of medicines and improves in quality of life of the patients.

What this study adds to existing knowledge? The present study used the nasal symptom score to assess the results of using isotonic saline irrigation in patients of allergic rhinitis. The score is a very simple and valid instrument to diagnose and to monitor the treatment of allergic rhinitis. The use of this score in routine practice is desirable. The practice of advising isotonic saline irrigation in allergic rhinitis should be enhanced because it is an easy, well tolerated and effective complementary therapy with no adverse effects.

\section{Author contributions}

- Concept and design, Patient care, approval for final print: Dr. Rajiv Kumar Saxena

- Data collection, interpretation of data, write up, data analysis: Dr. Hemendra Bamaniya

- Guidance, final revision: Dr. H.S Bhuie

Funding: Nil, Conflict of interest: Nil

Permission from IRB: Yes

\section{References}

1. Stuck BA, Czajkowski J, Hagner AE, et al. Changes in daytime sleepiness, quality of life, and objective sleep patterns in seasonal allergic rhinitis: a controlled clinical trial. J Allergy Clin Immunol.2004 Apr;113(4) : 663-8. DOI:10.1016/j.jaci.2003.12.589

2. Juniper EF. Impact of upper respiratory allergic diseases on quality of life. J Allergy Clin Immunol. 1998 Feb;101(2 Pt 2):S386-91.

3. Marshall PS, O'Hara C, Steinberg P. Effects of seasonal allergic rhinitis on fatigue levels and mood. Psychosom Med. 2002 Jul-Aug;64(4):684-91.
4. Bousquet J, Neukirch F, Bousquet PJ, et al. Severity and impairment of allergic rhinitis in patients consulting in primary care. J Allergy Clin Immunol. 2006 Jan; 117 (1) : 158-62. Epub 2005 Dec 2.

5. Tanner LA, Reilly M, Meltzer EO, Bradford JE, Mason J. Effect of fexofenadine hydrochloride on quality of life and work, classroom, and daily activity impairment in patients with seasonal allergic rhinitis. Am J Managed Care. 1999 April; 5 (4): S 235S247.

6. Blanc PD, Trupin L, Eisner M, et al. The work impact of asthma and rhinitis: findings from a population-based survey. J Clin Epidemiol. 2001 Jun; 54 (6):610-8.

7. Wilken JA, Berkowitz R, Kane R. Decrements in vigilance and cognitive functioning associated with ragweed-induced allergic rhinitis. Ann Allergy Asthma Immunol. 2002 Oct;89(4):372-80. DOI:10.1016/S10811206 (10)62038-8

8. Marshall PS, O'Hara C, Steinberg P. Effects of seasonal allergic rhinitis on selected cognitive abilities. Ann Allergy Asthma Immunol. 2000 Apr;84(4):403-10. DOI:10.1016/S1081-1206(10)62273-9

9. Vuurman EF, van Veggel LM, et al. Seasonal allergic rhinitis and antihistamine effects on children's learning. Ann Allergy. 1993 Aug;71(2):121-6.

10. Léger D, Annesi-Maesano I, Carat F, et al. Allergic rhinitis and its consequences on quality of sleep: An unexplored area. Arch Intern Med. 2006 Sep 18;166 (16) : 1744-8.

11. Rama, S.; Ballentine, R.; Hymes, A. Science of Breath: A Practical Guide; Himalayan Institute Press: Honesdale, PA, USA, 1998.

12. Burns JL. Nasal lavage. J Otolaryngol. 1992 Apr;21 (2): 83 .

13. Sur DK, Plesa ML. Treatment of Allergic Rhinitis. Am Fam Physician. 2015 Dec 1;92 (11): 98592.

14. Benninger MS, Holy CE, Trask DK. Acute Rhinosinusitis: Prescription Patterns in a Real-World Setting. Otolaryngol Head Neck Surg. 2016 May;154 (5) : 957-62. doi: 10.1177/ 0194599816630310. Epub 2016 Mar 1. 
15. Rudmik L, Hoy M, Schlosser RJ, et al. Topical therapies in the management of chronic rhinosinusitis: an evidence-based review with recommendations. Int Forum Allergy Rhinol. 2013 Apr; 3(4):281-98. doi: 10. 1002 / alr. 21096. Epub 2012 Oct 8.

16.Beswick DM, Ramadan H, Baroody FM, etal.Practice patterns in pediatric chronic rhinosinusitis: A survey of the American Rhinologic Society. Am J Rhinol Allergy. 2016 Nov 1;30(6): 418-423.doi: 10. 2500 / ajra. 2016. 30.4373 .

17. Marchisio P, Picca M, Torretta S, et al. Nasal saline irrigation in preschool children: a survey of attitudes and prescribing habits of primary care pediatricians working in northern Italy. Ital J Pediatr. 2014 May 15;40:47. doi: 10.1186/1824-7288-40-47.

18. Werner Garavello, Marco Romagnoli, Lorenza Sordo, Renato Maria Gaini, Cristina Di Berardino, Alfonso Angrisano. Hypersaline nasal irrigation in children with symptomatic seasonal allergic rhinitis: A randomized study. Pediatr Allergy Immunol 2003 April; 14 (2): 140-143.

19. Karadag A. Nasal saline for acute sinusitis. Pediatrics. 2002 Jan;109(1):165.

20. Kurtaran H, Karadag A, Catal F, et al. A reappraisal of nasal saline solution use in chronic sinusitis. Chest. 2003 Nov; 124 (5): 2036-7; author reply 2037-8.

21. Ponikau JU, Sherris DA, Kephart GM, et al. Striking deposition of toxic eosinophil major basic protein in mucus:implications for chronic rhinosinusitis. J Allergy Clin Immunol. 2005 Aug; 116 (2): 362-9. DOI: $10.1016 /$ j.jaci.2005.03.049

22. Georgitis JW. Nasal hyperthermia and simple irrigation for perennial rhinitis. Changes in inflammatory mediators. Chest. 1994 Nov;106(5):148792
23. Talbot AR, Herr TM, Parsons DS. Mucociliary clearance and buffered hypertonic saline solution. Laryngoscope. 1997 Apr;107(4):500-3.

24. Boek WM, Graamans K, Natzijl H, et al. Nasal mucociliary transport: new evidence for a key role of ciliary beat frequency. Laryngoscope. 2002 Mar;112 (3): 570-3. DOI:10.1097/00005537-200203000-00029

25. Holmström M, Rosén G, Wåhlander L. Effect of nasal lavage on nasal symptoms and physiology in wood industry workers. Rhinology. 1997 Sep;35(3): 108-12.

26. Shoseyov D, Bibi H, Shai P, et al. Treatment with hypertonic saline versus normal saline nasal wash of pediatric chronic sinusitis. J Allergy Clin Immunol. 1998 May;101(5):602-5. DOI:10.1016/ S0091-6749(98) 70166-6

27. Baraniuk JN, Ali M, Yuta A, et al. Hypertonic saline nasal provocation stimulates nociceptive nerves, substance $\mathrm{P}$ release, and glandular mucous exocytosis in normal humans. Am J Respir Crit Care Med. 1999 Aug; 160(2):655-62. DOI:10.1164/ajrccm.160. 2.9805081

28. Rabago D, Pasic T, Zgierska A, et al. The efficacy of hypertonic saline nasal irrigation for chronic sinonasal symptoms. Otolaryngol Head Neck Surg. 2005 Jul;133(1):3-8. DOI:10.1016/j.otohns.2005.03.002

29. Schmidt Th, Bitzer EM, Dorning H, et al. Daily nasal rinse reduces airway discomfort- a randomized crossover study. Das Gesundheitswesen(The Health Service) 2004; 66-124.DOI: 10.1055 / s-2004-833862

30. Nsouli TM, Schluckebier CD, McSorley-Gerard EJ, et al. Long-term use of nasal saline irrigation: harmful or helpful? Ann Allery Asthma Immunol. 2009; 103 (suppl 3):A3-A14. (Abstracts of the 2009 annual meeting of the American College of Allergy, Asthma, and Immunology, Miami, FL, November 5-10, 2009.)

How to cite this article?

Saxena R.K, Bamaniya H, Bhuie H.S. Role of nasal douching in chronic allergic rhinitis. Trop J Ophthalmol Otolaryngol. 2019;4(2):109-113.doi: 10.17511/jooo.2019.i02.07 